\title{
POTENSI MADU LEBAH LIAR DAN TERNAK SEBAGAI OBAT LUKA BAKAR SECARA IN VIVO
}

\author{
Andi Nurazmi*, Laode Rijai, Dewi Rahmawati \\ Laboratorium Penelitian dan Pengembangan FARMAKA TROPIS \\ Fakultas Farmasi Universitas Mulawarman, Samarinda, Kalimantan Timur \\ *Email: nurazmi.andi@yahoo.com
}

\begin{abstract}
ABSTRAK
Luka bakar adalah suatu cedera yang disebabkan oleh panas, arus listrik dan bahan kimia yang mengena kulit, mukosa dan jaringan dalam. Penanganan dalam penyembuhan luka bakar dapat dilakukan dengan menggunakan madu. Efektivitas madu dalam proses penyembuhan luka bakar dipicu oleh adanya aktivitas antibakteri, pembentukan kolagen dan sisa-sisa sel epitel. Penelitian ini bertujuan untuk mengetahui kemungkinan adanya potensi dan perbedaan madu lebah liar, madu lebah ternak, dan obat bioplacenton dalam menyembuhkan luka bakar. Penelitian ini, dengan pendekatan in vivo, menggunakan 12 ekor tikus putih (Rattus norvegicus) yang dibagi menjadi 4 kelompok (3 tikus dalam setiap kelompok), yaitu: kontrol normal (KN), kelompok pembanding dengan obat bioplacenton (KP), kelompok eksperimen 1 dengan madu lebah liar (KL), dan kelompok eksperimen 2 dengan madu lebah ternak (KT). Dengan pemberian perlakuan pengobatan luka bakar pada punggung tikus, ditemukan bahwa penggunaan obat bioplacenton paling efektif dengan lama waktu penyembuhan 19,7 hari, kemudian madu lebah liar yaitu 21 hari, dan madu lebah ternak yaitu 22 hari. Sementara, tanpa pengobatan diketahui bahwa penyembuhannya lebih lambat yaitu 24,7 hari.
\end{abstract}

Kata Kunci: Bioplacenton, Kulit, Penyembuhan, Tikus Putih

\begin{abstract}
Burnt injury can be caused by heat, electric current and chemicals on the skin, mucosa and deeper tissues. To heal burnt injury can be handled by using bee honey. The effectiveness of bees honey in the healing of burnt injury can be done by antibacterial activities, collagen formation and epithelial cells remnants. The aim of this research is to see the potential possibilities and differences of using wild-, and livestock bee honey, and bioplacenton drugs to heal burnt injury. The research, by in vivo approach, used 12 rats (Rattus norvegicus), consisting 4 groups (3 rats in each group), viz: standart of comparison group with bioplacenton drug $(K P)$, experiment 1 group with wild bee honey $(K L)$, experiment 2 group with livestock bee honey $(K T)$, and normal control group $(K N)$. The research results showed that, using bioplacenton drug is the most effective by longer healing time is 19,7 days, then wild bee honey is 21 days, and livestock bee honey is 22 days. Meanwhile, without treatment is known that healing is slower, viz 24,7 days.
\end{abstract}

Keywords: Bioplacenton, Healing, Rats, Skin 


\section{PENDAHULUAN}

Luka bakar adalah cedera disebabkan oleh panas, arus listrik, dan bahan kimia yang mengenai kulit, mukosa dan jaringan yang lebih dalam. Penanganan dalam penyembuhan luka bakar antara lain mencegah infeksi dan memberi kesempatan sisa-sisa sel epitel untuk berproliferasi dan menutup permukaan luka (Corwin, 2000).

Pengobatan secara tradisional sebagai alternatif untuk menyembuhkan luka akhirakhir ini banyak digunakan. Salah satunya dengan menggunakan madu. Di bidang kesehatan, madu mendapatkan perhatian untuk digunakan sebagai agen antibakteri dalam perawatan luka bakar maupun luka lainnya. Menurut Rio (2012), madu dapat mempercepat proses penyembuhan luka bakar karena adanya aktivitas antibakteri. Sifat antibakteri dari madu disebabkan karena madu memiliki tekanan osmotik dan $\mathrm{pH}$ yang baik sehingga mencegah pertumbuhan mikroba, serta adanya kandungan polifenol, flavonoid, dan glikosida yang berfungsi sebagai antibakteri. Selain itu, menurut Balqis (2014), madu dapat memacu pembentukan kolagen dan sisa-sisa sel epitel karena kandungan fruktosa sebagai sumber nutrisi kulit, serta kandungan enzimnya.

Madu lebah liar umumnya diyakini oleh sebagian masyarakat lebih berkhasiat dibandingkan dengan madu ternak. Hal ini dikarenakan terdapat perbedaan dari jenis lebahnya, perlakuannya, dan standar kadar airnya. Lebah liar umumnya dari jenis Apis dorsata, sedangkan madu ternak dari jenis Apis cerana, Apis trigona, Apis indica dan Apis melifera, sehingga akan mempengaruhi madu yang dihasilkan. Madu lebah liar umumnya tidak dapat ditangkarkan sedangkan madu lebah ternak dapat ditangkarkan, sehingga madu lebah liar tidak dapat diberikan suplemen makanan tambahan, sedangkan madu ternak umumnya diberikan suplemen tambahan seperti gula tebu dan sirup gula. Kemudian terdapat pula perbedaan kadar air dari kedua madu tersebut, standar air madu liar adalah 24 $\%$ sedangkan madu ternak sekitar $21 \%$.

Penelitian ini bertujuan untuk mengetahui kemungkinan adanya potensi dan perbedaan madu lebah liar, madu lebah ternak, dan obat bioplacenton dalam menyembuhkan luka bakar. Berdasarkan hal tersebut, maka peneliti tertarik untuk mengetahui potensi madu lebah liar dan ternak untuk pengobatan luka bakar secara in vivo.

\section{METODE PENELITIAN}

\section{Bahan}

Madu lebah liar dan ternak, obat Bioplacenton, $\mathrm{NaCl}$ 0,9\%, Lidokain, Alkohol 70\%, kertas kalkir, kassa, ulrafix, kapas dan Cotton bud.

\section{Peralatan}

Plat logam $1 \mathrm{~cm}$, Oven, Timbangan Analitik, pinset. pisau cukur, dan gunting.

\section{Prosedur}

\section{a. Pengumpulan Sampel Madu}

Madu lebah ternak yang digunakan adalah madu yang diperoleh dari peternakan lebah di kecamatan Muara Kumam, kabupaten Pasir, Kalimantan Timur, sedangkan madu lebah liar diperoleh dari daerah kecamatan Muara Samu. Madu lebah ternak dan madu lebah liar yang digunakan adalah madu murni (100\%) yang akan langsung diberikan pada tikus putih (Rattus norvegicus) tanpa adanya pengenceran terlebih dahulu. Pada kelompok pembanding digunakan obat rasional untuk yaitu bioplacenton. 


\section{b. Penyiapan Hewan Coba}

Hewan uji yang digunakan adalah tikus putih (Rattus norvegicus) sebanyak 12 ekor yang dibagi menjadi 4 kelompok yang terdiri atas 3 ekor tikus.

\section{c. Pengujian Luka Bakar}

\section{1) Tikus Dilukai Tanpa Diberi Madu}

Disiapkan 5 ekor tikus. Sehari sebelum perlakuan, dicukur bulu pada bagian punggung tikus. Saat hari pengujian, tikus dianastesi dengan menggunakan bahan penganastesi yaitu injeksi lidokain secara intramuskular pada tikus putih. Setelah itu, kulit punggung tikus yang telah dicukur dibersihkan dengan menggunakan alkohol $70 \%$, lalu dibuat luka bakar derajat dua dangkal dengan menggunakan plat logam berdiameter $1 \mathrm{~cm}$ yang dioven pada hingga suhu $100^{\circ} \mathrm{C}$, kemudian ditempelkan pada punggung tikus selama 15 detik. Setelah dilakukan luka bakar, diberi larutan irigasi dengan menggunakan $\mathrm{NaCl}$ 0,9\%. Kemudian dilakukan pengamatan hingga luka bakar sembuh dan tertutup dengan baik.

\section{2) Tikus Dilukai Diberi Madu}

\section{a) Madu Lebah Ternak}

Disiapkan 5 ekor tikus. Sehari sebelum perlakuan, dicukur bulu pada bagian punggung tikus. Saat hari pengujian, tikus dianastesi dengan menggunakan bahan penganastesi yaitu injeksi lidokain secara intramuskular pada tikus putih. Setelah itu, kulit punggung tikus yang telah dicukur dibersihkan dengan menggunakan alkohol $70 \%$, lalu dibuat luka bakar derajat dua dangkal dengan menggunakan plat logam berdiameter $1 \mathrm{~cm}$ yang dioven pada hingga suhu $100^{\circ} \mathrm{C}$, kemudian ditempelkan pada punggung tikus selama 15 detik. Setelah dilakukan luka bakar, diberi larutan irigasi dengan menggunakan $\mathrm{NaCl}$ $0,9 \%$. Setelah itu langsung diberikan madu lebah ternak pada punggung tikus yang telah dilakukan luka bakar, kemudian dihitung sebagai hari ke-0 pemberian. Selanjutnya madu lebah ternak secara kontinyu diberikan pada tikus sebanyak 2 kali sehari pagi dan sore. Kemudian dilakukan pengamatan hingga luka bakar sembuh dan tertutup dengan baik.

\section{b) Madu Lebah Liar}

Disiapkan 5 ekor tikus. Sehari sebelum perlakuan, dicukur bulu pada bagian punggung tikus. Saat hari pengujian, tikus dianastesi dengan menggunakan bahan penganastesi yaitu injeksi lidokain secara intramuskular pada tikus putih. Setelah itu, kulit punggung tikus yang telah dicukur dibersihkan dengan menggunakan alkohol 70\%, lalu dibuat luka bakar derajat dua dangkal dengan menggunakan plat logam berdiameter $1 \mathrm{~cm}$ yang dioven pada hingga suhu $100^{\circ} \mathrm{C}$, kemudian ditempelkan pada punggung tikus selama 15 detik. Setelah dilakukan luka bakar, diberi larutan irigasi dengan menggunakan $\mathrm{NaCl} 0,9 \%$. Setelah itu langsung diberikan madu lebah liar pada punggung tikus yang telah dilakukan luka bakar, kemudian dihitung sebagai hari ke-0 pemberian. Selanjutnya madu lebah liar secara kontinyu diberikan pada tikus sebanyak 2 kali sehari pagi dan sore. Kemudian dilakukan pengamatan hingga luka bakar sembuh dan tertutup dengan baik.

\section{3) Tikus Dilukai Diberi Obat Bioplacenton}

Disiapkan 5 ekor tikus. Sehari sebelum perlakuan, dicukur bulu pada bagian punggung tikus. Saat hari pengujian, tikus dianastesi dengan menggunakan bahan penganastesi yaitu injeksi lidokain secara intramuskular pada tikus putih. Setelah itu, kulit punggung tikus yang telah dicukur dibersihkan dengan menggunakan alkohol 70\%, lalu dibuat luka bakar 
derajat dua dangkal dengan menggunakan plat logam berdiameter $1 \mathrm{~cm}$ yang dioven pada hingga suhu $100^{\circ} \mathrm{C}$, kemudian ditempelkan pada punggung tikus selama 15 detik. Setelah dilakukan luka bakar, diberi larutan irigasi dengan menggunakan $\mathrm{NaCl} 0,9 \%$. Setelah itu langsung diberikan obat bioplacenton pada punggung tikus yang telah dilakukan luka bakar, kemudian dihitung sebagai hari ke-0 pemberian. Selanjutnya obat bioplacenton secara kontinyu diberikan pada tikus sebanyak 2 kali sehari pagi dan sore. Kemudian dilakukan pengamatan hingga luka bakar sembuh dan tertutup dengan baik.

\section{HASIL DAN PEMBAHASAN}
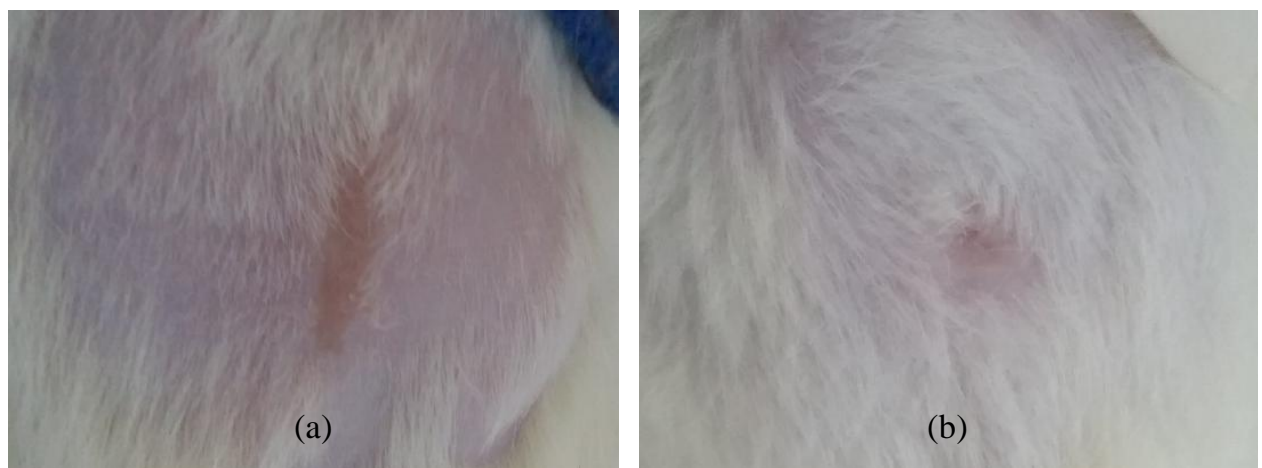

(c)

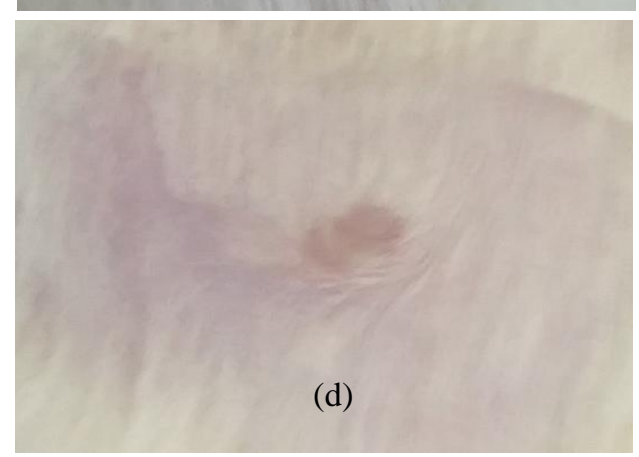

Gambar 1. Foto kesembuhan luka bakar (a) Kelompok Kontrol normal, (b) Kelompok pembanding (c) Kelompok Eksperimen 1 dengan madu lebah liar, (d) Kelompok Eksperimen 2 dengan madu lebah ternak.

Tabel 1. Penilaian kesembuhan luka bakar dari masing-masing kelompok

\begin{tabular}{lccc}
\hline \multicolumn{1}{c}{ Kelompok } & Replikasi & $\begin{array}{c}\text { Lama Waktu } \\
\text { Penyembuhan (Hari) }\end{array}$ & $\begin{array}{c}\text { Rata-rata lama } \\
\text { waktu penyembuhan }\end{array}$ \\
\hline Kontrol Normal & 1 & 25 & 24,7 \\
Kelompok Pembanding & 2 & 23 & \\
dengan obat Bioplacenton & 3 & 26 & 19,7 \\
Madu Lebah Liar & 2 & 19 & \\
& 3 & 20 & 21 \\
Madu Lebah Ternak & 1 & 20 & \\
& 2 & 21 & 22 \\
& 3 & 22 & \\
\hline
\end{tabular}


Berdasarkan tabel 1 didapatkan bahwa rata-rata lama waktu penyembuhan pada kelompok kontrol normal adalah 24,7 hari, sedangkan pada kelompok pembanding dengan obat bioplacenton adalah 19,7 hari. Kelompok madu lebah liar memiliki rata-rata waktu penyembuhan adalah 21 hari, dan madu lebah ternak adalah 22 hari.

Dari pernyataan di atas dapat diambil kesimpulan bahwa perawatan dengan menggunakan obat bioplacenton lebih cepat dalam menyembuhkan luka bakar, kemudian madu lebah liar, dan madu lebah ternak. Sementara, tanpa pengobatan diketahui bahwa penyembuhannya lebih lambat, Hal ini dapat diketahui dengan diagram yang terlihat pada gambar 1.

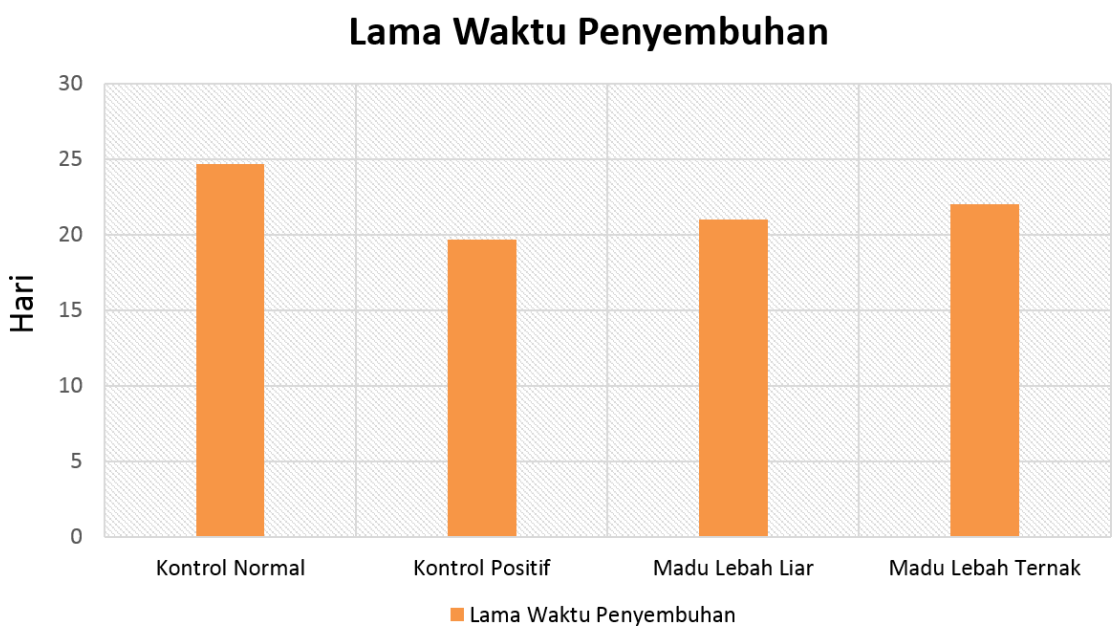

Gambar 1. Rata-rata lama waktu penyembuhan

Pada gambar diagram tersebut, diketahui bahwa rata-rata lama waktu penyembuhan yang paling cepat adalah dengan menggunakan obat bioplacenton, kemudian dengan menggunakan madu lebah liar, dan selanjutnya dengan menggunakan madu lebah ternak. Sementara, tanpa pengobatan diketahui bahwa penyembuhannya lebih lambat.

Berdasarkan hasil penelitian yang diperoleh, diketahui potensi madu lebah liar dan ternak lebih efektif dibandingkan kontrol normal yang tidak diberikan perlakuan. Hal ini dikarenakan madu lebah liar dan ternak diketahui memiliki beberapa kandungan berkhasiat yaitu fruktosa, beberapa senyawa metabolit sekunder (glikosida, polifenol, dan flavonoid) dan beberapa enzim (invertase, glukosa oksidase, dan peroksidase). Kandungan tersebut berkhasiat untuk menyembuhkan luka bakar karena sifat antibakterinya dan memacu pembentukan kolagen serta mengupayakan agar sisa-sisa sel epitel dapat berkembang kembali. Sedangkan pada kontrol normal, tidak diberikan pengobatan apapun, hal ini akan menghambat proses penyembuhan dari luka bakar tersebut, sehingga dibutuhkan waktu yang lebih lama untuk sembuh.

Pada penelitian ini, diketahui pula bahwa madu lebah liar berpotensi lebih cepat untuk menyembuhkan dibandingkan dengan madu lebah ternak. Hal ini disebabkan karena kandungan senyawa dari madu lebah liar yang lebih tinggi. Kandungan yang tinggi tersebut diperoleh dari sumber nektar dari lebah madu liar yang lebih beragam (multiflora), sehingga senyawa bioaktif yang dihasilkan pun lebih tinggi dan beragam pula. Sedangkan pada madu lebah ternak, memiliki kandungan yang berasal dari salah satu tanaman dominan (monoflora), hal inipun akan berpengaruh pada kandungan dari hasil madu yang diperoleh. Namun, pengobatan dengan obat bioplacenton lebih cepat menyembuhkan 
dibandingkan dengan madu lebah liar. Hal ini disebabkan oleh potensi kandungan ekstrak plasenta dan neomisin sulfat dari obat bioplacenton yang langsung bekerja sebagai agen antibakteri dan mempercepat regenerasi sel yang baik pada luka bakar.

\section{KESIMPULAN}

Hasil penelitian yang telah dilakukan dapat disimpulkan bahwa potensi obat bioplacenton dalam menyembuhkan luka bakar lebih efektif, kemudian madu lebah liar, dan madu lebah ternak. Sementara, tanpa pengobatan diketahui bahwa penyembuhannya lebih lambat.

\section{DAFTAR PUSTAKA}

1. Balqis, Ummu, dkk. 2014. Gambaran Histopatologis Penyembuhan Luka Bakar Menggunakan Daun Kedondong (Spondias Dulcis F.) Dan Minyak Kelapa Pada Tikus Putih (Rattus Norvegicus). Jurnal Medika Veterinaria. Volume 8 Nomor 1.

2. Corwin, Elizabeth J. 2000. Buku Saku Patofisiologi. EGC. Jakarta.

3. Rio, dkk. 2012. Perbandingan Efek Antibakteri Madu Asli Sikabu dengan Madu Lubuk Minturun terhadap Escherichia Coli dan Staphylococcus Aureus secara In Vitro. Jurnal Kesehatan Andalas. Volume 1 Nomor 2. 